\title{
How to Choose and Work with Lawyers and Clients: A Bahamian \& Caribbean Perspective
}

\author{
Peter D. Maynard \\ Law Department \\ University of The Bahamas
}

\begin{abstract}
Apart from the substance of a transaction or dispute, what factors should inform the decision to choose or work with a particular lawyer or client? This article, born of a series of conferences on the subject, deals with conflicts of interest, lawyer-client communication, attorney-client privilege, retainers, due diligence, engagement letters and whether lawyers can engage in alternative business structures other than partnerships. These are all pressing topics relating to law practice as we approach the end of the first quarter of the 21 st century.
\end{abstract}

\section{Introduction}

There could be nothing more important than having high moral and ethical standards as a legal practitioner and judge (The Right Honourable Sir Dennis Byron, former President of the Caribbean Court of Justice at the Graduation at Hugh Wooding Law School, 2013).

For two consecutive years, 2014 and 2015, conferences were held at the University of The Bahamas under the theme "How to Choose and Work with Lawyers and Clients." Partners included the Council of Legal Education, Eugene Dupuch Law School, and selected law firms and lawyers. The University of The Bahamas Law Department treated this conference as part of its commitment to look into the present condition and future of the profession. The organizers aspired to shape this event into an opportunity to engage practitioners, students and the public in the region as a whole. After an interlude of a year, the event has rotated to Jamaica in the form of this panel, and hopefully panels or conferences like it will also regularly emerge in other regional jurisdictions in the years to come. ${ }^{1}$ Fundamentally, the objective was to secure great value for lawyers across the wider region by deepening their involvement with other lawyers, institutions and international law organizations. The event was also a celebration of increased globalization and regionalism, and of the tremendous power mobilized by working together. In addition, while ethics are fundamental to the practice of law, they can sometimes be dull and even boring; the event set out to marry ethics with more alluring topics, such as law firm management (and in due course trial advocacy), in order to convey vital, practical information. Therefore, the event is still a work in progress, and the Jamaica session is

\footnotetext{
1 The author expresses warm thanks to Norman Clark and Steven Richman for cooperating on this project as well as Jacqueline CummingsGordon, Georgia Gibson-Henlin, Maxine MooreThomas, Sasha-Kay Gilzean, Teri-Ann Lawson, Candice Stewart, and Sherry Ann McGregor of the Jamaican Bar Association for incorporating this session into its Weekend Conference, Montego Bay, November 16-19, 2017.
} 
an important stage in its evolution.

This article relates primarily to The Bahamas and the Caribbean but some issues are of general application. This paper aims to give a broad overview of a sample of practice issues, such as (1) conflicts of interest, (2) lawyer-client communication, (3) engagement letters and billing, (4) "clients from hell," and a day in the life of an associate. The paper also touches on other questions, notably: can lawyers in the region (e.g., Bahamas, Dominica, Guyana, Jamaica, and Trinidad \& Tobago) organize themselves in limited liability companies, instead of partnerships? Can lawyers in those countries form multi-disciplinary partnerships (MDPs), i.e., go into business with other professionals such as accountants, architects, engineers, and surveyors, as in the United Kingdom and elsewhere? Is it in the cards for any Commonwealth Caribbean law firm to be incorporated and sell shares to the public on the stock exchange or privately? These are all huge topics and just one of them needs more space than can be allocated to this paper. Therefore, this paper is an overview not intended to deal with each topic exhaustively but to spark discussion and debate.

\section{Conflicts of Interest}

When taking on a new client and forming an attorney-client relationship, it is key firstly to do a conflict check. One has to be cognizant and forthright about what is a conflict of interest. For example, under the Bahamas code of professional conduct, Rule V states:

Save after adequate disclosure in writing to and with the consent of the client or prospective client concerned, the attorney must not advise or represent more than one interest in a matter nor shall he act or continue to act in a matter when there is or is likely to be a conflicting interest. A conflicting interest is one which would be likely to affect adversely the judgment of the attorney on behalf of or his loyalty to a client or prospective client or which the attorney might be prompted to prefer to the interest of a client or prospective client (Bahamas Bar (Code of Professional Conduct) Regulations, 1981, p. 15).

Similarly under Canon IV of Jamaica's Legal Profession (Canons of Professional Ethics) Rules:

An Attorney shall act in the best interest of his client and represent him honestly, competently and zealously within the bounds of the law. He shall preserve the confidence of his client and avoid Conflicts of Interest (1978, p. 285).

The Canon goes further in $(\mathrm{m})$ and states "in all situations where a possible conflict of interest arises, an attorney shall resolve all doubts against the propriety of multiple representation" (Legal Professions (Canons of Professional Ethics) Rules, 1978, p. 286). Conflicts of interest cannot be exhaustively listed. They may include any number of situations, such as: mobility of lawyers within the profession where there is a live issue about the misuse of confidential information (MacDonald Estate v. Martin, 1990); a lawyer representing the accused and co-accused on charge of conspiracy (R. V. Silvini, 1991); a lawyer for the wife in matrimonial proceedings sharing office space with the lawyer retained by the husband (Baumgartner v. Baumgartner, 1994); a member of the plaintiff's former solicitors joining the defendant's solicitors (Alrich Development Pte Ltd v. Rafiq Jumabhoy, 1995), including merger of firms (Berg v. Bruton, 2005); the plaintiff's lawyer transferring to the defendant's law firm during the course of litigation (Bank of 
Montreal v. Dresler, 2002); or an alleged conflict resulting from a lawyer's family relations where he represented a defendant and his father represented a party adverse to interests of the defendant (R. v. Clarke, 2012). In another 2012 example, a Queen's Counsel and his then partner were fined $£ 12,000$ and $£ 3,000$ respectively by the Solicitors Disciplinary Tribunal because of conflicts of interest in representing parties on both sides of a dispute and divulging documents to them ("Hopper Puts the Case", 2012).

Each situation is determined based on its own facts and may or may not amount to a conflict of interest requiring the lawyer not to act. ${ }^{2}$ Furthermore, where a conflict arises, clients must be informed. They may mutually consent to the representation by the lawyer. If the lawyer is dismissed by one client during that mutual representation, he or she cannot continue to represent the others; he or she should completely withdraw from representing any of them.

\section{Lawyer-Client Communication}

For ethics and disciplinary committees around the world, lack of communication or inadequate communication with clients is a primary complaint. Clear and frequent communication with your client is very important. It is necessary not only to listen to and understand the client's problem and also to communicate to him or her what you intend to do about it, and when, where and at what cost. Legal fees, court fees and any other costs should be fully explained in advance and at each stage to the client. I inform new attorneys that, when they feel that lump in their throats, they should swallow it, and exhale full and frank advice to clients about what financial commitments

2 For example, in R. v. Clarke (2012, footnote 15 supra), the son-father adverse representation did not amount to a conflict of interest. and risks they are undertaking, even at the risk of losing the clients.

Bad communication figures among the top perennial complaints against lawyers. That includes refusal and tardiness in returning phone calls, failure to meet, failure to explain fees, among other things. The relationship should be based on trust. Good communication builds trust. The client also employs the lawyer to communicate with other parties and the court on his or her behalf; so the lawyer should start with and maintain good communication with the client.

\section{Attorney-Client Privilege}

With ongoing litigation in Jamaica and stagnant litigation in The Bahamas (e.g. Morris, 2003), this subject is at a critical juncture in the region. Within the Bahamas Bar code of conduct, Rule IV deals with confidentiality and attorney-client privilege. Paragraph 2 of the commentary to that Rule states that:

This ethical rule must be distinguished from the evidentiary rule of lawyer and client privilege with respect to oral or documentary communications passing between the client and his attorney. The ethical rule is wider and applies without regard to the nature or source of the information or the fact that others may share the knowledge (Bahamas Bar (Code of Professional Conduct) Regulations, 1981, p. 14).

Attorney-client privilege is a key feature that distinguishes a lawyer from other professions. Within the attorney-client relationship, the privilege is the client's and attorneys must safeguard it unless it is explicitly waived by the client. That is to say, privilege cannot be maintained by an attorney if it involves the commission or facilitation of a crime. It is to be noted that 
attorney-client privilege is not to benefit the attorney but the client.

Jamaica and Canada made remarkable progress on this issue which I believe should be proactively shared with other jurisdictions. In Jamaica Bar Association v. Attorney General and General Legal Council (2017), the Bar successfully upheld lawyerclient privilege in relation to the disclosures of client information required under the proceeds of crime legislation. This took place in the aftermath of successful Canadian litigation on this subject (Federation of Law Societies of Canada v. Canada [Attorney General], 2011).

\section{Retainer and Engagement Letter}

The engagement letter/retainer is utilized to memorialize the terms of the client-attorney agreement, by clearly expressing the scope of services that the attorney is to provide for the client and the fees. Therefore, once there is no conflict of interest, the attorney or law firm should obtain due diligence information, an engagement letter and the retainer from the client.

\section{Due Diligence}

One of the purposes of the due diligence exercise, also known as Know Your Client or $\mathrm{KYC}$, is to ensure that the client is not engaging the firm to facilitate any illegal act and to ensure that the client has not derived monies from illegitimate sources. The due diligence form should verify:

a. The full and correct name of client;

b. Permanent Address;

c. Purpose of Facility;

d. Potential Activity;

e. Occupation;

f. Copy of Identification;

g. Telephone contacts.

\section{Engagement Letter}

The engagement letter should be detailed and have several different sections to assist in clarity. First, the introduction should thank the client for instructing you and clearly identify the client, whether an individual, or entity. The introduction should also indicate what the attorney is being asked to do to ensure that there is no miscommunication. The engagement letter should acknowledge how payment will be accepted, whether wire, or cheque and the hourly rates. The engagement letter should also discuss termination as a client may terminate a retainer at any time and for any reason. However, the attorney or law firm should encourage the client to resolve their issues with the firm prior to terminating the relationship. The engagement letter should also advise the client that the attorney or law firm is entitled to terminate the attorneyclient relationship for several reasons which may include:

a. if the client does not pay one or more of invoices, or;

b. if the client does not make an advance payment promptly when required to do so, or;

c. if the client's instructions are unreasonable or would require a breach of a professional rule or a duty to the court or involve the commission of a criminal offence.

The agreed retainer should be placed in a clients' account and the attorney should bill against the retainer if that is the agreement with the client. The engagement letter should also identify the law and jurisdiction governing the engagement letter. If a client is overseas, the engagement letter should also agree that all signatures evidenced by facsimile transmission or electronic mail will be accepted as original signatures.

\section{Clients from Hell}

Not all clients are from heaven. Some do not even seem to be from this earthly plane. 
This is the client who would like constantly to look over your shoulder, who is never satisfied with anything you do, and who really deep down thinks he is a better lawyer than you. To give two examples, sometimes a frank talk, referring the client to another lawyer in the firm or a timely bill will solve the problem. Sometimes those measures do not work. After you have applied all of your skills to no avail to arrive at a truce, can you withdraw from working for a client from hell?

Regional codes usually permit you to withdraw. It is probably a good idea to do so rather than compound the problem, or force the issue by continuing to represent a dissatisfied client. For example, (e) of Canon III of Jamaica's Legal Profession (Canons of Professional Ethics) Rules, "An attorney shall not (except for good reasons) refuse his services in Capital offences" (1978, p. 284). In England and Wales, refusal of service is permissible only on reasonable grounds and not on a discriminatory basis; improper refusal may result in a complaint to the Legal Ombudsman (e.g. Solicitors Regulation Authority, 2011).

\section{Alternative Business Structures}

Regional lawyers traditionally practice in partnerships. The partners can be held personally liable and do not have the benefit of limited liability. The formation of limited liability companies (LLCs) or professional limited liability companies (PLLCs) for lawyers would be relatively unprecedented in the region. LLCs or PLLCs are common in the United States. In some regional countries, law firms operate companies that provide corporate and financial services, such as company formation, registered office and registered agent. For example, in The Bahamas, lawyers can establish such companies under the Financial and
Corporate Service Providers Act. However, this is a limited exception and does not extend to the entire practice.

What are Alternative Business Structures? An alternative business structure (ABS) is an entity that, while providing regulated reserved legal activities, also allows nonlawyers to own and/or invest in law firms. There are approximately four different ABS models:

1. Legal service entity providing legal services only in which individuals who are not licensed attorneys own a minority interest in the entity;

2. Legal service entity providing legal services only in which there are no restrictions on non-lawyer ownership;

3 . Business entity providing legal and nonlegal services in which non-lawyers own a minority interest in the entity; and

4. Business entity providing legal and nonlegal services in which there are no restrictions on non-lawyer ownership.

What jurisdictions presently allow for an ABS? The Legal Services Act 2007 of England allows non-lawyers to own and invest in law firms. ABSs have been permitted since 2007 although the first licenses were issued in 2012. Barnes Roffe Legal is an ABS in England that is categorized as the first type of ABS. Price Bailey was the United Kingdom's first accounting firm to be officially recognized as an ABS.

In Australia, alterations for attorney regulations began in New South Wales in the 1990s. Attorneys were permitted to form MDPs (also known as ABS) with other professionals, and ultimately allowed to incorporate. Australia's Slater \& Gordon became the first publicly-traded law firm in the world in 2007 (Hill, 2014, p. 20). MDPs are also allowed in three provinces in Canada, namely, British Columbia, Ontario, 
and Quebec. The Canadian Bar Association, established the International Practice of Law (IPL) Committee in 1997 in order to monitor the development of multi-disciplinary practices (Hill, 2014, p. 22). Pursuant thereto, a 1998 IPL committee report asserted that, "unless [multidisciplinary practice organizations] were controlled by lawyers," they should not be permitted to provide legal services to clients. Subsequently, the IPL committee revised its view in 1999 and recommended that lawyers be allowed to participate in multidisciplinary practices, even if such practices were not controlled by lawyers and were not limited to those of a "legal nature" (Hill, 2014).

The American Bar Association (ABA) stood firm. In 2000, a recommendation was approved that it is "inconsistent with the profession's core values for lawyers and non-lawyers to share fees, for non-lawyers to own or control a law firm" (Matheson \& Favorite, 2001). However, the ABA position seems to be softening. The first paragraph of a recent recommendation lends itself to the interpretation that law firms may sell their shares to non-lawyers. The recommendation states:

Lawyers should be permitted to share fees and join with non-lawyer professionals in a practice that delivers both legal and non-legal professional services (Multidisciplinary Practice), provided that the lawyers have the control and authority necessary to assure lawyer independence in the rendering of legal services. "Non-lawyer professionals" means members of recognized professions or other disciplines that are governed by ethical standards. (American Bar Association, 2010)

On October 7, 2014, the Ministry of Law of Singapore submitted the Legal Profession
(Amendment) Bill 2014 for its First Reading in Parliament which permits ABSs. The Bill was adopted as law in Parliament on November 4, 2014. ABSs or Legal Disciplinary Practices (LDPs) are permitted, where non-lawyer managers/employees will be allowed to own equity and/or share in the profits of LDPs, and LDPs will only be allowed to provide legal services (e.g. Melnitzer, 2014).

But, how does an ABS affect privilege? Australia's Legal Profession Act, 2004, section 143(3) expressly provides that the law relating to client legal privilege (or other professional privilege) is not excluded or otherwise affected because an Australian legal practitioner is acting in the capacity of an officer or employee of an incorporated legal practice. In England and Wales, under section 190 of the Legal Services Act 2007, privilege applies to communications made by an ABS, provided that the communications are made through, or under the supervision of, a lawyer.

An ABS or MDP may not measure up to the lawyer's ethical obligations. There are standards of confidentiality and privilege different from those of other professionals such as accountants. For example, regarding Jamaica, clients have a right to attorney/client privilege ${ }^{3}$ as illustrated in Canon IV (t)(i) and (ii) of the Legal Profession (Canons of Professional Ethics) Rules. It states that "an Attorney shall not knowingly reveal a confidence or secret of his client, or use a confidence or secret of his client to the client's disadvantage or to his own advantage" (1978, p. 287). Also, pursuant to Rule IV of the Bahamas Bar (Code of Professional Conduct) Regulations,

An attorney has a duty to hold in strict

3) am cognizant of ongoing litigation on this subject in Jamaica, and refrain with reluctance from commenting on it, as it is sub judice. 
confidence all information received in the course of the professional relationship from or concerning his client or his client's affairs which information should not be divulged by the attorney unless he is expressly or impliedly authorized by his client or required by the Commonwealth of The Bahamas to do so (1981, p. 14).

An accountant/client privilege does not exist and the accountant would be required to disclose any information the client has revealed. This distinction is vital and the assessment should not be taken nonchalantly.

The lack of an accountant/client privilege was illustrated in the American case of United States v Arthur Young \& Co. (1984). In this case the respondent certified public accountant firm, as an independent auditor for the respondent corporation and was responsible for reviewing the corporation's financial statements. When a routine audit by the Internal Revenue Service (IRS) issued a criminal investigation of the corporation's tax returns, the IRS summoned the accountant firm to make available all files of the corporation. The accountant firm refused, relying on accountant/client privilege. Nevertheless, the court rejected the accountant/client privilege argument and applied Couch v. United States (1973) which held that no confidential accountantclient privilege exists. The lack of confidentially other professionals may have with regard to a client is a deterrent to operating as an ABS or MDP.

\section{What are the benefits of an ABS?}

1. Equity can be raised from a broader base of potential partners, members or directors for example from other professions who are not attorneys.

2. The ability to diversify the range of legal services provided by the practice and becoming a "one stop shop".

3. Equity can be raised from outside the legal sector without the need for nonlawyer involvement at the management level. This has the potential to allow firms to attract new investment from different markets.

Australia became the pioneer as it relates to selling shares in its firms. In 2007, Slater \& Gordon became the first law firm in the world to be publicly traded, listing shares on the Australian Stock Exchange. Gately was the second firm in the world to sell shares, and the first in the United Kingdom (Rogerson, 2016). To date there are only a few law firms that have done this, but many countries are following suit. A general concern about selling their shares is that by doing so, and by having non-lawyers hold these shares there may be conflicts of interest and breaches in professional codes of conduct such as concluding matters as quickly as possible regardless of the result in order to satisfy shareholders and to provide higher shareholder value (Rogerson, 2016). 


\section{References}

Alrich Development Pte Ltd v. Rafiq Jumabhoy, (No 2) 2 SLR(R) 340 (1995)

American Bar Association. (2000). Commission on multidisciplinary practice report to the house of delegates. Retrieved from https://www.americanbar.org/groups/profe ssional_responsibility/commission_multid isciplinary_practice/mdpfinalrep2000.html

Bahamas Bar (Code of Professional Conduct) Regulations. (1981). Retrieved from http://laws.bahamas.gov.bs/cms/images/L EGISLATION/SUBORDINATE/1981/19 81-0022/BahamasBarCodeofProfessional ConductRegulations_1.pdf

Bank of Montreal v. Dresler, 224 DLR (4th) 337 (2002)

Baumgartner v. Baumgartner, 113 DLR (4th) 579 (1994)

Berg v. Bruton, 273 SaskR 181 (2005)

Couch v. United States, 409 US 322 (1973)

Federation of Law Societies of Canada v. Canada (Attorney General), BCSC 1270 (2011)

Hill, L. L. (2014). The preclusion of nonlawyer ownership of law firms: Protecting the interest of clients or protecting the interests of lawyers? Capital University Law Review, 42, 907949. Retrieved from https://heinonline.org/HOL/P?h=hein.jour nals/capulr42\&i $=941$

Hopper puts the case against "overly aggressive" SRA. (2012, November 1). Legal Futures. Retrieved from http://www.legalfutures.co.uk/latestnews/hopper-puts-case-against-overlyaggressive-sra

Jamaica Bar Association v. Attorney General \& General Legal Council, JMFC Full 02
(2017)

Legal Profession (Canons of Professional Ethics) Rules, Jamaica. (1979). Available at https://www.generallegalcouncil.org /legislation/

MacDonald Estate v. Martin, SCJ No. 41 (1990)

Matheson, J. H., \& Favorite, P. D. (2001). Multidisciplinary practice and the future of the legal profession: Considering a role for independent directors. Loyola

University Chicago Law Journal, 32, 577616. Retrieved from https://lawecommons.luc.edu/cgi/viewcon tent.cgi article $=1350 \&$ context $=l u c l j$

Melnitzer, J. (2014, January 30). Alternative business structures spread to Singapore. Financial Post. Retrieved from http://business.financialpost.com/legalpost/alternative-business-structuresspread-to-singapore/wcm/18fa1614-518446ce-98fc-c19a11af7fb 1

Morris, G. (2003, August 2). Privy Council forces rejection of Bahamas Court of Appeal position. Retrieved from http://www.bahamasb2b.com/news/wmvie w.php?ArtID=2105

R. v. Clarke, NSSC 406 (2012)

R. v. Silvini, 68 CCC (3d) 251 (1991)

Rogerson, P. (2016, June 8). Gateley float makes history as rival firms wait in wings. Law Society Gazette. Retrieved from https://www.lawgazette.co.uk/practice/gat eley-stock-exchange-float-makes-history/5049258.article

Solicitors Regulation Authority. (2011). SRA code of conduct. Retrieved from www.sra.org.uk/solicitors/handbook/code/ content.page

United States v. Arthur Young \& Co, 465 US 805 (1984) 